\title{
Therapeutic effects of aqueous, methanol and ethanol extracts of Egyptian Artemisia herba-alba in STZ-induced diabetic neuropathy in rats
}

\author{
Salma A. El-Marasy ${ }^{1}$, Eman R. Zaki ${ }^{2}$, Heba M.I. Abdallah ${ }^{1 *}$, Mahmoud S. Arbid ${ }^{1}$ \\ ${ }^{1}$ Pharmacology Department, National Research Centre, Giza, Egypt. \\ ${ }^{2}$ Department of Molecular Biology, National Research Centre, Giza, Egypt.
}

\section{ARTICLE INFO \\ Article history: \\ Received on: 13/12/2016 \\ Accepted on: 08/02/2017 \\ Available online: $30 / 03 / 2017$}

\section{Key words:}

Artemisia herba-alba;

diabetes; neuropathy; STZ;

oxidative stress.

\begin{abstract}
Diabetes mellitus is a common cause of peripheral neuropathy and patients suffer from chronic peripheral pain. Artemisia herba-alba $(\mathrm{Ah})$ is a prevalent plant with extensive traditional uses. This study aimed to investigate the therapeutic effects of Ah in STZ-model of diabetic peripheral neuropathy. After induction of diabetes, rats were treated with aqueous, $100 \%$ methanol and $70 \%$ ethanol extracts of $\mathrm{Ah}$ at doses of 50 and $100 \mathrm{mg} / \mathrm{kg}$ for each extract; respectively. Behavioral tests (Tail flick, hot plate and locomotor activity) were performed on animals. Blood glucose was measured in serum and oxidative stress biomarkers (GSH, MDA, CAT and GST) were assessed in isolated sciatic nerve. Treatment with aqueous, methanol and ethanol extracts of Ah decreased blood glucose level increased tail withdrawal latency and retention time (in tail flick and hot plate tests; respectively) and increased diabetic rats movements in the activity cage. The extracts also inhibited oxidative stress status by decreasing lipid peroxidation and enhancing GSH and antioxidant enzymes; CAT and GST. Therefore, treatment with Ah ameliorated painful diabetic neuropathy in STZ rats which was evident by improved nociceptive latency and locomotor activity. The therapeutic effect of the plant could be mediated by antioxidant mechanisms.
\end{abstract}

\section{INTRODUCTION}

Neuropathic pain arises due to many reasons, namely injurious CNS diseases e.g. multiple sclerosis, viral infections and postsurgical pain. Neuropathic differs from algesic pain in that it is not protective, but rather pathological. The classical type of painful neuropathy occurs during diabetes mellitus (Boulton, 2004). There are three major complications of diabetes mellitus "DM"; namely diabetic nephropathy, neuropathy and retinopathy. These conditions cause further complications e.g. renal failure, sensory/motor loss and blindness (Fowler, 2008). Diabetic neuropathy (DN) is a devastating problem and leads to foot amputation. Diabetes induces inappropriate expression of sensory mediators resulting in electrophysiological disturbances due to a complex network of correlated vascular, metabolic and

* Corresponding Author

Email:heba21_5@yahoo.com sensory mediators resulting in electrophysiological disturbances due to a complex network of correlated vascular, metabolic and neurotropic defects (Edwards et al., 2008). Essentially, chronic pain resulted from peripheral nerve damage has a negative impact on diabetic patients' activity. It affects bothtype- 1 and type-2 diabetic patients, resulting in disabilities besides a high mortality rate (Callaghan et al., 2012). Furthermore, it is severe and chronic clinical issue that presents resistance to some classical analgesics (Gilron et al., 2006). Neuropathic pain is also presented with positive symptoms like pricking and pain. Negative symptoms also occur including loss of sensation, hyperalgesia, paresthesias, allodynia and diminished strength (Melton and Dyck, 1999). Reduced glycemic control leads to activation of several biochemical pathways that ends in nerve damage. When glucose concentration is high, glucose uptake by cells is shifted toward insulin-independent mechanisms. Increased intracellular glucose level activate polyol pathway, which is regulated by aldose 
reductase (AR) and sorbitol dehydrogenase activities. Glucose and sorbitol are converted to sorbitol and fructose by the effect of AR and sorbitol dehydrogenase; respectively (Brownlee, 2005). When AR activity predominates, sorbitol accumulates inside cells, raises osmotic pressure and thus producing oxidative cell damage (Chung et al., 2003). Therapies for DN are restricted due to lack of established mechanisms for the neuropathic pain. Interventions targeted to halt sensory pathways without treating the pathological basis of pain are often ineffective (Vincent et al., 2011). However, there are different options for treatment of the disease. Fundamental treatments are currently directed to prevent DN through adequate glycemic control to prevent further nerve damage (Tesfaye et al., 2007). Additionally, drug treatments aimed to minimize pain and its associated symptoms have been produced such as tricyclic antidepressants, anticonvulsants and serotonin reuptake inhibitors (Tesfaye et al., 2010). Oxidative stress is a mutual pathway of cell injury as a result of hyperglycemia. Using antioxidant approaches have been widely investigated but only $\alpha$-lipoic acid has shown promise in clinical trials (Ziegler et al., 2006). Due to various side effects of drug therapy, other measures like physical treatment could alleviate symptoms. These include electrical stimulation of nerves, posture training, manual therapy, foot care, hot wax and phototherapy (Pieber et al., 2010; Balbinot et al., 2012). However, seeking efficient treatment for this condition remains a great challenge.

Artemisia herba-alba (Ah) is a known herb that has beneficial properties as a herbal Further studies are needed to integrate this popular plant in human health care system (Moufid and Eddouks, 2012). In our previous studies, Ah was shown to be effective as anti-inflammatory, antinociceptive, antipyretic and gastro-protective agent (Abdel Jaleel et al., 2016). In addition, it was concluded that the total alcoholic extract of Ah could be used as antidiabetic agent. It was found to exhibit antihyperglycemic, antihyperlipidemic and protective against hepatic and renal toxicities in a rat model of induced type1 diabetes (Abdallah et al., 2015). The current work was conducted to extend the use of the Egyptian Ah as a potential treatment of diabetic complications. The study aims to examine the therapeutic potential of this herb on the progress of behavioral as well as biochemical deficits in diabetic neuropathy.

\section{MATERIAL AND METHODS}

\section{Plant material}

The dried aerial parts of the Ah were purchased from the Egyptian markets and were grinded by electric grinder.

\section{Preparation of plant extract}

The plant powder was soaked in $70 \%$ ethyl alcohol for about 3 days, filtered using filter paper and the filtrate was concentrated under vacuum using the rotating evaporator (Rotavap), then percolated several times till exhaustion. The total alcoholic (70\% ethanol) extract was obtained. Then the residual plant was further extracted with methanol. The obtained 100\% methanol extract was filtered, dried and stored in the refrigerator at $4{ }^{\circ} \mathrm{C}$ till further use. For preparation of aqueous extract, the aboveground parts of Ah were also powdered and dissolved in distilled water for $16 \mathrm{~h}$ with occasionally shaking each $2 \mathrm{~h}$. The extract was filtered. The filtrate was concentrated under vacuum using the rotating evaporator (Rotavap), and then percolated several times till exhaustion. The obtained aqueous extract of Ah was also used for pharmacological screening. The yield of each extract was also recorded; ethanol (27.5\%), methanol (19\%) and aqueous (34.5\%)

\section{Phytochemical study}

Chemical analysis for the presence of potential compounds as well as antioxidant activity was performed for the three extracts of Ah; ethanol, methanol and aqueous extracts (the extraction procedures mentioned above). Values were expressed and calculated based on weight ( $g$ ) of dry tissue (the main powder weight before extraction).

\section{Determination of total phenolic content}

Total concentration of phenolic compounds in the extracts was determined using a series of gallic acid standard solutions $(2.5-20 \mu \mathrm{g} / \mathrm{ml})$ as described by Singleton and Rossi (1965) but with some modifications. Each extract solution $(0.1 \mathrm{ml})$ was mixed with $2 \mathrm{ml}$ of a $2 \%(\mathrm{w} / \mathrm{v})$ sodium carbonate solution and vortexed vigorously. The same procedure was also applied to the standard solutions of gallic acid. After $3 \mathrm{~min}, 0.1 \mathrm{ml}$ of Folin Ciocalteau's phenol reagent was added and each mixture was vortexed again. The absorbance at $750 \mathrm{~nm}$ of each mixture was measured, after incubation for $30 \mathrm{~min}$ at room temperature. Total phenolic content was expressed as mg gallic acid/ g dry tissue.

\section{Determination of total flavonoid content}

Total concentration of flavonoid compounds in extracts was determined using a series of standard rutin solutions (2.5-50 $\mu \mathrm{g} / \mathrm{ml})$ as described in the aluminum chloride colorimetric method. A known volume of each extract solution was mixed with $5 \%$ sodium nitrite solution, vortexed vigorously, then $10 \%$ aluminum chloride solution was added and vortexed again. After 6 min, $4.3 \%$ of sodium hydroxide solution was added, followed by addition of water, shaken, and left to stand for $15 \mathrm{~min}$ before determination. The sample solution without coloration was used as reference solution and the color was read at $510 \mathrm{~nm}$ wavelength (Dae-Ok et al., 2003). Total flavonoid content was expressed as $\mathrm{mg}$ rutin/g dry tissue.

\section{Free radical scavenging activity by DPPH method}

The free radical scavenging activities were determined by DPPH method with some modifications of the method proposed by Blois (1958). Briefly, a $0.1 \mathrm{mM}$ solution of DPPH in absolute ethanol was prepared. The initial absorbance of the DPPH in ethanol was measured at $517 \mathrm{~nm}$ (absorbance 1.3) and did not change throughout the period of assay. A series of extract solutions or ascorbic acid (standard antioxidant) with varying concentrations were prepared by dissolving the dried extracts in 
ethanol and $0.1 \mathrm{ml}$ of solutions from each extract was added to 1.4 $\mathrm{ml}$ of DPPH solution. The absorbance at $517 \mathrm{~nm}$ was recorded after $30 \mathrm{~min}$ of incubation at room temperature. Radical scavenging capacity of each extract has been calculated as the percent inhibition of DPPH radical (scavenging effect)as follows:

$\%$ of inhibition $=[(\mathrm{A} 1-\mathrm{A} 0 / \mathrm{A} 0)] \times 100$

Where, A0 is the absorbance of the control with ethanol and A1 is the absorbance of the sample in the presence of the extract samples. IC50 value was determined from the graph of percentage of inhibition plotted against the log concentration of the extract using GraphPadPrism Software 6.0. IC50 is defined as the concentration of extract needed to inhibit $50 \%$ of DPPH radicals.

\section{Animals}

Healthy male Wister rats, weighing 220-250 g, were obtained from the animal house of the National Research Centre (Giza, Egypt). Before initiating the experiments, the rats were allowed to acclimatize for few days under standard environmental conditions $\left(12 \mathrm{~h}\right.$ dark $/ 12 \mathrm{~h}$ light cycle; temperature $20-22^{\circ} \mathrm{C}$; relative humidity $40 \%-60 \%$ ). The study was conducted according to regulations of the ethics committee of the National Research Centre which gave its consent in accordance with the Guide for the Care and Use of Laboratory Animals of the National Institutes of Health and complies with the guidelines from the Canadian Council on Animal Care. To minimize animal suffering, number of animals were kept as minimum as possible to perform suitable statistical analysis. After finishing the experiment and all measurements, animals were sacrificed by decapitation using sharp scissors which is rapid and painless.

\section{Induction of Diabetes}

Type $1 \mathrm{DM}$ was induced by a single i.p. injection of a freshly prepared solution of streptozotocin (STZ) $(52.5 \mathrm{mg} / \mathrm{kg}$ body weight) in $0.1 \mathrm{M}$ citrate buffer ( $\mathrm{pH} 4.3$ ) after a fasting period of $24 \mathrm{~h}$ (Barrière et al., 2012; Mohan et al., 2013). On the third day of STZ injection, diabetes in surviving rats was confirmed by measuring the glucose level of blood obtained from the tail vein. Rats with a plasma glucose level of $180 \mathrm{mg} / \mathrm{dl}$ or greater were accepted as diabetic and included in this study.

\section{Experimental design}

After induction of diabetes, rats were divided into seven equal groups (eight rats per group). Group 2 (control positive) comprises rats that received STZ as mentioned above. Groups 3,4 comprises rats that received STZ and oral administration of the Ah aqueous extract at $50 \& 100 \mathrm{mg} / \mathrm{kg}$; respectively. Doses were selected based on previous studies (Abdallah et al., 2015). Groups 5,6 comprises rats that received STZ and oral administration of the Ah methanolic extract at $50 \& 100 \mathrm{mg} / \mathrm{kg}$; respectively. Groups 7, 8 comprises rats that received STZ and oral administration of the $\mathrm{Ah}$ ethanolic extract at $50 \& 100 \mathrm{mg} / \mathrm{kg}$; respectively. The first group (control negative group) comprises normal rats that received only $1 \mathrm{ml}$ saline. Treatment with the Ah extract was started three days after STZ injection. Each plant extract was given p.o. at the selected doses based on toxicity study (data not shown) daily to diabetic rats for 28 days. Thermal algesia was assessed using Tail flick and hot plate tests at the end of the experiment, whereas, locomotor activity was assessed before and after treatment. Blood samples were collected from retro-orbital plexus of only 6 animals in each group under light ether anaesthesia and centrifuged by cooling centrifuge (Sigma and laborzentrifugen, 2k15, Germany) at $3000 \mathrm{rpm}$. The obtained serum samples were immediately analyzed for glucose concentration using available kits (Stanbio Laboratory, USA). Then behavioral tests were performed on 8 animals from each group in order to achieve adequate statistical analysis as follows:

\section{Thermal nociceptive response Tail flick test}

The method described by Sugimoto et al. (2008) used with slight modifications. Acute nociception was induced by using a tail flick apparatus (Tail Flick model DS 20 Sorrel Apelex, France). Briefly, each rat placed in a restrainer and the tail flick latency was determined by focusing the intensity controlled beam of light on the distal last $2 \mathrm{~cm}$ of the animal's tail and recording the time in seconds taken to remove the tail from the noxious thermal stimulus. For each animal, 2 to 3 recordings were made at an interval of $15 \mathrm{~min}$; the mean value was used for statistical analysis.

\section{Hot plate test}

The protocol of determination of analgesic activity using hot plate method was published by Woolfe and Mc Donald (1962). This test measures the time that elapses before the rat demonstrates hind paw licking/shaking and jumping, which indicate pain in response to the applied heat. Each animal was placed onto a Perspex cylinder on the heated stage maintained at $52+0.5^{\circ} \mathrm{C}$ hot plate to perform the test. Latency to exhibit nociceptive responses was determined in seconds. To avoid tissue damage of the rat paws, cutoff time for the response to thermal stimulus was set at 60 seconds.

\section{Locomotor activity test}

Spontaneous locomotor activity of the rats was measured by using a grid floor activity cage (Model No. 7430, Ugo-Basile, Comerio, Italy) to detect the rat's movements. Movements by the rat that interrupted infrared beams were automatically detected, and the beam-interruption information was processed by the activity cage software to provide counts of horizontal movements. Before STZ injection, rats were acclimated to the test room for $1 \mathrm{~h}$. Then, each rat was placed individually into the activity cage for a 5 min session and the basal activity counts were recorded. At the end of the session, each rat was gently removed from the activity cage, and then returned to their home cage. The arena was wiped out with a $70 \%(\mathrm{v} / \mathrm{v})$ alcohol solution in distilled water between sessions to prevent olfactory cues. Twenty-four hours after the last administration of the test drugs, each rat was then re-exposed to the activity apparatus. The final activity counts were recorded per 
5 min, with each count indicating one beam break by the animal (Thome et al., 2001).

\section{Isolation of sciatic nerve}

Sciatic nerves were rapidly removed as per the procedure described by Mizisin (2004) from the spin to the peroneal bifurcation and rinsed in ice cold saline solution and frozen at -80 ${ }^{\circ} \mathrm{C}$. On the day of homogenate preparation sciatic nerve segments were measured and weighed. Sciatic nerves were cut into small pieces and then homogenized at $4^{\circ} \mathrm{C}$ in adequate volume of of $0.025 \mathrm{mM}$ Tris- $\mathrm{HCl}$ buffer, $\mathrm{pH} 8$, with glass homogenizer, resulting homogenate fitted with a Teflon pestle. The homogenates were centrifuged at $3400 \mathrm{xg}$ for 15 min using Beckman L5-50B ultracentrifuge with $220.78 \mathrm{VD} 2$ rotor at $4{ }^{\circ} \mathrm{C}$. The supernatants were filtered through a plug of glass wool to remove floating lipids, the cytosolic fractions were termed as crude homogenates of sciatic nerve and stored at $-20^{\circ} \mathrm{C}$ for further analyses. Oxidative stress biomarkers were estimated in sciatic nerve homogenate:

\section{Reduced glutathione content (GSH) and Lipid peroxides content}

Aliquots of the sciatic nerve homogenate were immediately used for estimation of Lipid peroxides (reflected by MDA concentration) \& GSH contents that were assayed colorimetrically according to the methods of Ohkawa et al. (1979) and Ellman (1959); respectively as previously described.

\section{Catalase (CAT) activity}

CAT activity is determined spectrophotometrically at $37^{\circ} \mathrm{C}$. The decomposition of $\mathrm{H}_{2} \mathrm{O}_{2}$ was followed as a decline in absorbance at $240 \mathrm{~nm}$ for 5 minutes (Aebi, 1984). The assay reaction mixture contained in a total volume of $3 \mathrm{ml}$, the substrate buffer and a suitable volume of the enzyme solution. The substrate buffer contains $30 \% \mathrm{H}_{2} \mathrm{O}_{2}$ in $100 \mathrm{ml}$ of $50 \mathrm{mM}$ potassium phosphate buffer, $\mathrm{pH}$ 7. The final concentration of $\mathrm{H}_{2} \mathrm{O}_{2}$ is 0.042 M. The activity of enzyme was expressed as $\mathrm{K}$ units of decomposed/min/mg proteins by the decomposition of $\mathrm{H}_{2} \mathrm{O}_{2}$ of the assay were followed at $240 \mathrm{~nm}$. The molar absorptivity of $\mathrm{H}_{2} \mathrm{O}_{2}=$ 43.6 $\mathrm{L} \mathrm{mol}^{-1} \mathrm{~cm}^{-1}$.

\section{(Glutathione-s-transferase GST) activity}

GST activity was determined according to the method described by Habig et al. (1974) by measuring the increase in the concentration of the conjugation product of GSH and 1-chloro-2,4dinitrobenzene $(\mathrm{CDNB})$ at $340 \mathrm{~nm}$ over $3 \mathrm{~min}$ at $25^{\circ} \mathrm{C}$. Unless otherwise stated, the assay mixture contained in a total volume of $1 \mathrm{ml}, 0.1 \mathrm{M}$ potassium phosphate buffer, $\mathrm{pH}$ 6.5, $1 \mathrm{mM}$ CDNB in ethanol (final concentration of ethanol less than $4 \%$ ), $1 \mathrm{mM} \mathrm{GSH}$, and the enzyme solution. One unit is equivalent to the amount of enzyme conjugating $1 \mu$ mole of CDNB in $1 \mathrm{~min}$ at $25^{\circ} \mathrm{C}$.

The extinction coefficient of the product was taken to be $9.6 \mathrm{mM}-1 \mathrm{~cm}-1$. Protein was estimated by the method of Bradford (1976) using bovine serum albumin as standard.

\section{Statistical analysis}

Statistical analysis for was carried out using One-way ANOVA followed by Tukey's post hoc test using SPSS software, version 14.0 (SPSS Inc., Chicago, Illinois, USA). For locomotor activity test, statistical significance was determined by two-way ANOVA was used as a statistical test followed by LSD multiple comparison post hoc test. Data were represented as mean \pm SEM. The $\mathrm{P}$ values less than 0.05 were considered to be significant.

\section{RESULTS}

\section{Phytochemical analysis/ antioxidant activity}

Phytochemical investigation showed that $70 \%$ ethanolic extract of Ah contains higher content of total phenolics (28.6 \pm $0.204 \mathrm{mg}$ gallic acid/g dry tissue and $6.215 \pm 0.58 \mathrm{mg}$ rutin/g dry tissue) than aqueous and methanol extracts and showed high antioxidant activities (IC50 $=0.65 \pm 0.08$ vs $0.63 \pm 0.03 \mathrm{mg} / \mathrm{mL}$ for ascorbic acid).

Table1: Phytochemical analysis/activity of Ah different extracts.

\begin{tabular}{|c|c|c|c|}
\hline Plant sample & $\begin{array}{l}\text { Total } \\
\text { phenolics } \\
\text { (mg gallic } \\
\text { acid/g dry } \\
\text { tissue) }\end{array}$ & $\begin{array}{l}\text { Total } \\
\text { flavonoids } \\
\text { (mg rutin/ g } \\
\text { dry tissue ) }\end{array}$ & $\begin{array}{c}\text { DPPH } * \text { IC }_{50} \\
(\mathrm{mg} \text { dry } \\
\text { tissue } / \mathrm{mL})\end{array}$ \\
\hline Ah aqueous extract & $6.31 \pm 0.5$ & $0.87 \pm 0.1$ & $3.9 \pm 0.2$ \\
\hline Ah methanol extract & $6.30 \pm 0.3$ & $0.96 \pm 0.03$ & $2.25 \pm 0.1$ \\
\hline Ah ethanol extract & $28.5 \pm 0.2$ & $6.22 \pm 0.6$ & $0.65 \pm 0.01$ \\
\hline \multicolumn{4}{|c|}{$\begin{array}{l}\text { Ah: Artemisia herba-alba. Results are represented as the mean values of three } \\
\text { replicates of the same sample } \pm \text { SE. Statistical analysis was performed using } \\
\text { one way ANOVA followed by Tukey as post hoc test. DPPH } \mathrm{IC}_{50} \text { of ascorbic } \\
\text { acid as stranded as scavenger for free radical }\left(0.63 \pm 0.03 \text { dry tissue } / \mathrm{mL} \text { ). * } \mathrm{IC}_{5}\right. \\
\text { (amount of extract which cause } 50 \% \text { inhibition of DPPH free radical). }\end{array}$} \\
\hline
\end{tabular}

\section{Effect on Fasting Blood glucose:}

Table 2 reveals that STZ injection induced hyperglycemia successfully. Treatment of animals with different extracts of Ah significantly decreased blood glucose as compared to STZ-diabetic group. Aqueous extract at $50 \& 100 \mathrm{mg} / \mathrm{kg}$, methanol extract at $50 \& 100 \mathrm{mg} / \mathrm{kg}$ and ethanol extract at $50 \& 100 \mathrm{mg} / \mathrm{kg}$ showed a decrease in blood glucose of $71 \%, 68 \%$, $75 \%, 79 \%, 74 \%$ \& $80 \%$; respectively.

Table 2: Effect of Ah different extracts on fasting blood glucose level after 3 days of STZ injection and after 28 days in rats:

\begin{tabular}{lll}
\hline & \multicolumn{2}{l}{ Blood glucose level (mg/dl) } \\
\hline Treatment & After 3 days & After 28 days \\
\hline Control negative (normal) & $109.5 \pm 5.7^{\mathrm{a}}$ & $106.2 \pm 5.2^{\mathrm{a}}$ \\
Control positive $(\mathrm{STZ})$ & $434.7 \pm 27.8^{*}$ & $438.0 \pm 30.1^{*}$ \\
Ah aqueous ext $(50 \mathrm{mg} / \mathrm{kg})$ & $449.0 \pm 15.5^{*}$ & $128.6 \pm 3.1^{\mathrm{a}}$ \\
Ah aqueous ext $(100 \mathrm{mg} / \mathrm{kg})$ & $429.5 \pm 34.8^{*}$ & $141.8 \pm 2.6^{\mathrm{a}}$ \\
Ah methanolic ext $(50 \mathrm{mg} / \mathrm{kg})$ & $420.5 \pm 24.0^{*}$ & $106.6 \pm 5.4^{\mathrm{a}}$ \\
Ah methanolic ext $(100 \mathrm{mg} / \mathrm{kg})$ & $358.5 \pm 22.4^{*}$ & $91.6 \pm 5.9^{\mathrm{a}}$ \\
Ah ethanolic ext $(50 \mathrm{mg} / \mathrm{kg})$ & $411 \pm 37.5^{*}$ & $113.8 \pm 3.9^{\mathrm{a}}$ \\
Ah ethanolic ext $(100 \mathrm{mg} / \mathrm{kg})$ & $362.5 \pm 21.0^{*}$ & $89.0 \pm 5.8^{\mathrm{a}}$ \\
\hline Ah: Artemisia herba-alba. All groups except normal were injected STZ \\
$(52.5 \mathrm{mg} / \mathrm{kg}$, once), s.c. Treatment started 3 days after STZ injection. Blood \\
glucose was measured twice; after 3days of STZ injection and at the end of the \\
experiment (after 28 days). Each value represents the mean glucose level \\
(mg/dl) \pm SEM (n=6). *Significantly different from control negative (saline) at \\
P<0.05, a significantly different from control positive (STZ) at P<0.05. One- \\
way ANOVA was used as a statistical test followed by Tukey's post hoc test.
\end{tabular}




\section{Effect on behavioral changes Tail Flick test}

A significant decrease $(\mathrm{P}<0.05)$ in tail flick latency was observed in diabetic rats (about 2 folds) compared to normal group and this decrease was markedly eliminated by $\mathrm{Ah}$ administration (Figure. 1). Aqueous extract at $50 \& 100 \mathrm{mg} / \mathrm{g}$, methanolic extract at $50 \& 100 \mathrm{mg}$, and ethanolic extract at 50\&100mg increased tail withdrawal latency by $74 \%, 107 \%, 82 \%, 46 \%, 54 \%, 100 \%$; respectively as compared to STZ-diabetic group.

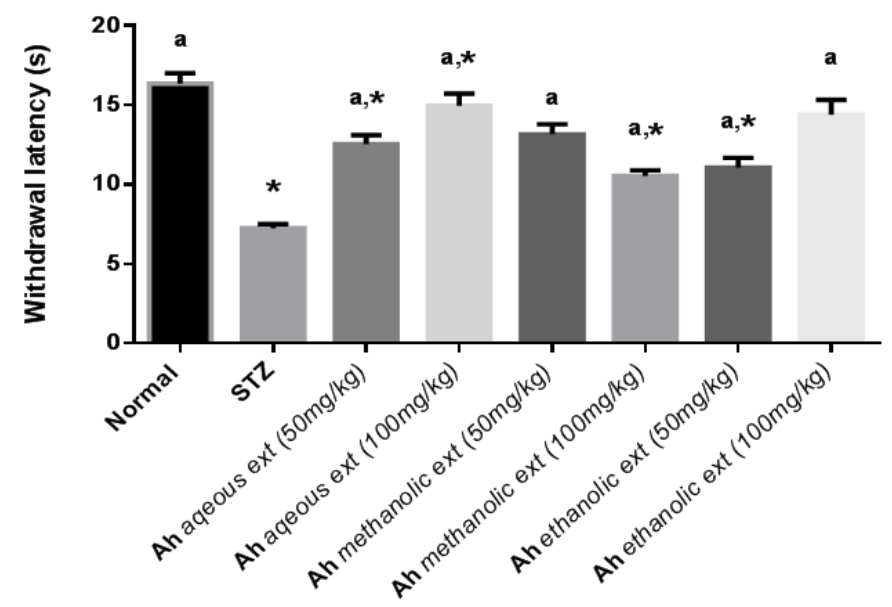

Fig. 1: Effect of Ah different extracts on thermally induced algesia using tail flick test in rats. One-way ANOVA with Tukey as post hoc test were applied. * Significantly different from normal group $(\mathrm{p}<0.05)$ and ${ }^{\text {a }}$ significantly different from STZ group $(\mathrm{p}<0.05)$. Values are expressed as Mean \pm SE $(\mathrm{n}=8)$. Ah: Artemisia herba-alba

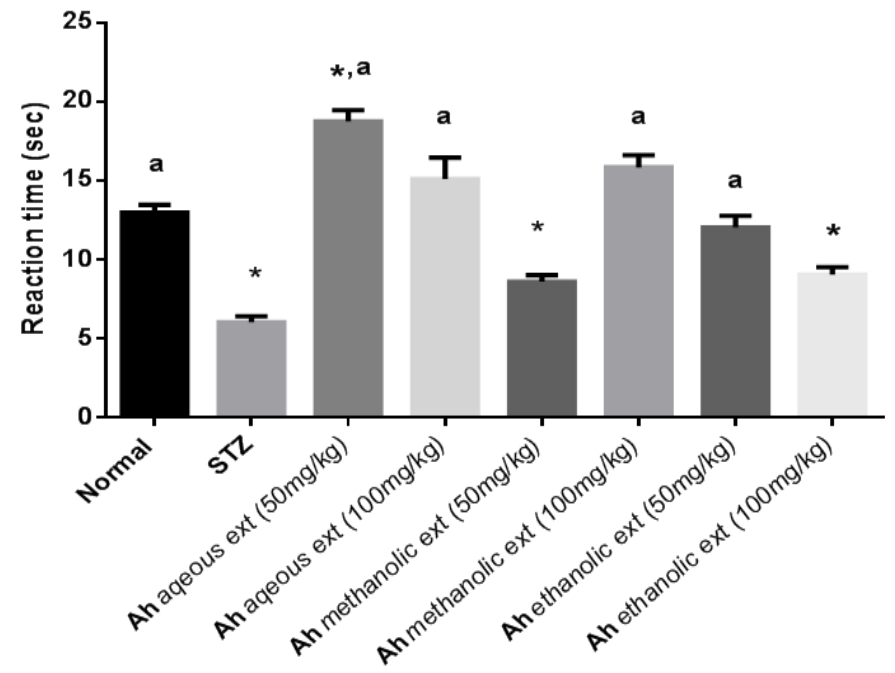

Fig. 2: Effect of Ah different extracts on thermally induced algesia using hotplate model in rats. One-way ANOVA with Tukey as post hoc test were applied. *Significantly different from normal group $(\mathrm{p}<0.05)$ and ${ }^{\mathrm{a}}$ Significantly different from STZ group $(\mathrm{p}<0.05)$. Values are expressed as Mean \pm SE $(\mathrm{n}=$ 8). Ah: Artemisia herba-alba.

\section{Hot plate test}

Figure. 2 shows that $\mathrm{STZ}$ significantly $(\mathrm{P}<0.05)$ decreased the retention time in hot plate as compared to the normal group. Administration of Ah aqueous ext. at $50 \& 100 \mathrm{mg} / \mathrm{kg}$, methanolic ext. at $100 \mathrm{mg} / \mathrm{kg}$, and ethanolic extract at $50 \mathrm{mg} / \mathrm{kg}$ increased the reaction time by $211 \%, 150 \%, 162 \%$, and $100 \%$ as compared to STZ-diabetic group.

\section{Locomotor activity test}

Normal, diabetic, and other-treated rats showed a significant reduction in their final locomotor activity with respect to their correspondent basal activity. A significant increase in the final locomotor activity of rats treated with aqueous $(50 \mathrm{mg} / \mathrm{kg})$, methanolic and ethanolic extracts of Ah was noticed as compared to the STZ-diabetic group (table 3).

Table 3: Effect of Ah different extracts on locomotor activity in activity cage test.

\begin{tabular}{|c|c|c|}
\hline \multirow[t]{2}{*}{ Treatments } & \multicolumn{2}{|c|}{$\begin{array}{c}\text { Locomotor activity } \\
\text { (counts/5 min) }\end{array}$} \\
\hline & Basal & Final \\
\hline Control negative (normal) & $169.63 \pm 17.43$ & $92.75 *^{* \dagger} \pm 12.06$ \\
\hline Control positive (STZ) & $133.67 \pm 2.88$ & $35.75^{*^{*}} \pm 4.64$ \\
\hline Ah aqueous ext $(50 \mathrm{mg} / \mathrm{kg})$ & $182.00 \pm 23.42$ & $100.67 *^{\dagger} \pm 11.90$ \\
\hline Ah aqueous ext $(100 \mathrm{mg} / \mathrm{kg})$ & $170.00 \pm 16.88$ & $53.67 *^{* \#} \pm 6.17$ \\
\hline Ah methanolicext $(50 \mathrm{mg} / \mathrm{kg})$ & $211.50 \pm 15.70$ & $102.00 * *^{\dagger} \pm 20.45$ \\
\hline Ah methanolicext $(100 \mathrm{mg} / \mathrm{kg})$ & $171.88 \pm 15.11$ & $92.50 *^{\dagger} \pm 17.48$ \\
\hline Ah ethanolicext $(50 \mathrm{mg} / \mathrm{kg})$ & $150.64 \pm 13.47$ & $80.43^{* \top} \pm 7.54$ \\
\hline Ah ethanolicext $(100 \mathrm{mg} / \mathrm{kg})$ & $207.83 \pm 8.37$ & $100.17 * *^{*} \pm 9.80$ \\
\hline
\end{tabular}

Ah: Artemisia herba-alba. All groups except normal were injected STZ $(52.5 \mathrm{mg} / \mathrm{kg}$, once), s.c. Treatment started 3 days after STZ injection. Results are expressed as mean \pm SEM $(n=8)$. *Significant difference from

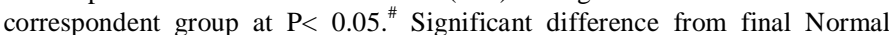
group at $\mathrm{P}<0.05{ }^{\dagger}$ Significant difference from final $\mathrm{STZ}$ group at $\mathrm{P}<0.05$. Two-way ANOVA was used as a statistical test followed by LSD multiple comparison post hoc test.

\section{Effect on oxidative stress biomarkers in sciatic nerve GSH and lipid peroxides contents}

Table 4 shows that STZ injection significantly $(\mathrm{p}<0.05)$ decreased GSH and increased lipid peroxides contents in sciatic nerve as compared with normal group. Treatment with aqueous, methanol and ethanol extracts at higher doses significantly increased GSH and all treatments significantly decreased lipid peroxide contents compared with STZ-diabetic control group. All extracts could bring lipid peroxide contents back to normal levels.

\section{CAT and GST activities}

In sciatic nerve, CAT \& GST activities were markedly inhibited in diabetic rats compared to control animals. These activities were significantly $(\mathrm{p}<0.05)$ enhanced in diabetic rats treated with different extracts when compared to untreated diabetic rats (table 4). 
Table 4: Effect of Ah different extracts on sciatic nerve oxidative stress biomarkers in rats.

\begin{tabular}{|c|c|c|c|c|}
\hline Treatment & $\begin{array}{c}\text { GSH } \\
(\mu \mathrm{M} / \mathrm{mg} \text { protein) }\end{array}$ & $\begin{array}{c}\text { MDA } \\
(\mu \mathrm{M} / \mathrm{mg} \text { protein) }\end{array}$ & $\begin{array}{c}\text { CAT activity } \\
\text { (unit/mg protein) }\end{array}$ & $\begin{array}{c}\text { GST activity } \\
\text { (unit/mg protein) }\end{array}$ \\
\hline Control negative (normal) & $2.63 \pm 0.24^{\mathrm{a}}$ & $0.22 \pm 0.02^{\mathrm{a}}$ & $25.68 \pm 1.19^{\mathrm{a}}$ & $0.299 \pm 0.023^{\mathrm{a}}$ \\
\hline Control positive (STZ) & $1.13 \pm 0.08^{*}$ & $0.47 \pm 0.03^{*}$ & $7.26 \pm 0.62^{*}$ & $0.170 \pm 0.013^{*}$ \\
\hline Ah aqueous ext $(50 \mathrm{mg} / \mathrm{kg})$ & $1.14 \pm 0.03^{*}$ & $0.37 \pm 0.02^{* \mathrm{a}}$ & $17.85 \pm 1.30^{* \mathrm{a}}$ & $0.297 \pm 0.018^{\mathrm{a}}$ \\
\hline Ah aqueous ext $(100 \mathrm{mg} / \mathrm{kg})$ & $2.39 \pm 0.22^{\mathrm{a}}$ & $0.26 \pm 0.01^{\mathrm{a}}$ & $16.82 \pm 1.51^{* a}$ & $0.276 \pm 0.015^{\mathrm{a}}$ \\
\hline Ah methanolic ext $(50 \mathrm{mg} / \mathrm{kg})$ & $1.84 \pm 0.19^{*}$ & $0.29 \pm 0.01^{\mathrm{a}}$ & $23.49 \pm 1.21^{\mathrm{a}}$ & $0.241 \pm 0.021^{\mathrm{a}}$ \\
\hline Ah methanolic ext $(100 \mathrm{mg} / \mathrm{kg})$ & $2.26 \pm 0.20^{\mathrm{a}}$ & $0.22 \pm 0.02^{\mathrm{a}}$ & $14.91 \pm 0.64^{* a}$ & $0.301 \pm 0.022^{\mathrm{a}}$ \\
\hline Ah ethanolic ext $(50 \mathrm{mg} / \mathrm{kg})$ & $1.91 \pm 0.15^{*}$ & $0.19 \pm 0.01^{\mathrm{a}}$ & $15.06 \pm 0.13^{* a}$ & $0.218 \pm 0.011^{\mathrm{a}}$ \\
\hline Ah ethanolic ext $(100 \mathrm{mg} / \mathrm{kg})$ & $2.67 \pm 0.33^{\mathrm{a}}$ & $0.15 \pm 0.01^{\mathrm{a}}$ & $16.74 \pm 1.67^{* a}$ & $0.270 \pm 0.017^{\mathrm{a}}$ \\
\hline
\end{tabular}

Ah: Artemisia herba-alba. All groups except normal were injected STZ $(52.5 \mathrm{mg} / \mathrm{kg}$, once), s.c. Treatment started 3 days after STZ injection. Each value represents the mean $\pm \operatorname{SEM}(\mathrm{n}=6)$. ${ }^{*}$ Significantly different from control negative (saline) at $\mathrm{p}<0.05,{ }^{\mathrm{a}}$ significantly different from control positive (STZ) at $\mathrm{P}<0.05$. One-way ANOVA was used as a statistical test followed by Tukey's post hoc test.

\section{DISCUSSION}

Neuropathic pain is amongst the basic complications of diabetes mellitus. About half of the diabetic patients develop neuropathy with manifestations such as spontaneous pain, allodynia and hyperalgesia (Apfel et al., 2001). Evaluation of behavioral reactions to foreign stimuli in animals developing diabetes gives profitable data regarding mechanisms mediating associated pain (Calcutt et al., 2004).

In the current work, tail flick and hot plate tests were used to estimate sensory responses as a result of thermal stimuli. STZ-diabetic rats exhibited significantly shorter tail withdrawal latency than that observed in normal animals. In addition, STZ injection showed significant hyperalgesia appeared in the hot-plate test. Hyperalgesia induced by STZ was tested in different experimental models and was found to produce various pathophysiological symptoms (Courteix et al., 1994; Hounsom and Tomlinson, 1997; Kamei et al., 2001). This also is in parallel with other previous studies that described thermal hyperalgesia resulted when the tail of STZ-diabetic animals was exposed to noxious stimuli (Ohsawa and Kamei, 1999; Kamboj et al., 2010). This induced nociception in the current study was accompanied with increased blood glucose in STZ group. Treatment with aqueous, methanolic and ethanolic extracts of Ah decreased blood glucose level and increased tail withdrawal latency and retention time. Mechanisms of induced diabetic neuropathy are complicated and overlapped. However, hyperglycemia is considered a primary factor in pain hypersensitivity accompanies diabetes as it causes direct toxicity in the peripheral nervous system. It enhances the activity of primary afferent fibers, potentiates glutamate release and diminishes the opioidergic and GABAergic inhibitory systems activities (Nourooz-Zadeh et al., 1997). Chronic hyperglycemia also causes alteration in sensitivity of the dopaminergic receptors as well as responsiveness of the dopaminergic system due to inclusion of the enkephalinergic system (Wohaieb and Godin, 1987). It affects L-type Ca2+ channels that are directly responsible for modulation of nociception in diabetic rats (Feillet-Coudray et al., 1999). In parallel, Ah extracts enhanced locomotor activity indicating that it was protective against neuronal damage. It was noticed that all groups showed reduction in their final locomotor activity with regard to their corresponding basal activity. This may be a result of rats' habituation to the activity cage. From above results, it is clear that proper adjustment of blood glucose could mitigate peripheral pain in long-lasting diabetes via direct mechanisms as established previously (Courteix et al., 1996).

It is well known that oxidative stress mediates sciatic nerve dysfunction and decreased blood flow in diabetic rats (Figueroa -Romero et al., 2008; Zherebitskaya et al., 2009; Aziza et al., 2014). Oxidative stress is induced by chronic hyperglycemia which induces auto-oxidation of monosaccharides. This causes superoxide and hydroxyl radicals to be evolved. Superoxide anions mediate a lot of the oxidative changes in hyperglycemic conditions, such as potentiating aldose reductase and protein kinase $\mathrm{C}$ activities which also have an impact on pain sensation (Kamei et al., 2001). The present results show that STZ injection for 28 days decrease GSH, increased lipid peroxidation and inhibited the activity of antioxidant enzymes; CAT and GST in sciatic nerve. CAT is responsible for the catalytic decomposition of $\mathrm{H}_{2} \mathrm{O}_{2}$ to oxygen and water. The decreased CAT activity during diabetes reduces protection against free radicals. Simultaneous reduction in SOD and CAT activities makes sciatic nerve more vulnerable to oxidative stress induced by chronic hyperglycemia. Similarly, GST and GSH-peroxidase work together with GSH in the decomposition of $\mathrm{H}_{2} \mathrm{O}_{2}$ or other organic hydroperoxides. A reduction in GST activity in diabetic rats might reflect decreased protein thiols as -SH groups play a critical role in enzyme catalysis (Mak et al., 1996). Treatment with Ah extracts enhanced GSH, decreased lipid peroxidation and retained the activity of CAT and GST in sciatic nerve indicating that this herb may exert the antinociceptive effect, in part, via its antioxidant properties. In a previous work of us, $70 \%$ ethanol extract of Ah was reported to possess antioxidant properties through scavenging DPPH free radical in-vitro (Abdel Jaleel et al., 2016). This antioxidant effect was ascribed to presence of high phenolic compounds including flavonoids and polyphenols (Abdallah et al., 2015). This challenged us to continue phytochemical and pharmacological investigation on other types of extracts for $\mathrm{Ah}$; aqueous and $100 \%$ methanol extracts. These extracts also produced neuroprotective effects comparable to the $70 \%$ ethanol one. 


\section{CONCLUSION}

Treatment with the three extracts of Artemisia herbaalba ameliorated peripheral pain which was evident by nociceptive latency in hot plate and tail flick tests as well as improved locomotor activity. It is proposed that the extracts act, in part, by anti-hyperglycemic and antioxidant mechanisms. Investigation of more mechanistic pathways is warranted in order to achieve efficient targeting of diabetic neuropathy as a major complication of D.M.

\section{ACKNOWLEDGMENTS}

Authors acknowledge Dr. Yosra Assem [Pharmacology department, National Research Centre, Giza, Egypt] for her sincere help in performing the current experimental work. This work was supported by the National Research Centre [Grant number 10010307] through funding the research, supplying materials, animals and all necessary facilities to conduct this study.

Conflict of Interests: There are no conflicts of interest.

\section{REFERENCES}

Abdallah HMI, Abdel-Rahman RF, Abdel Jaleel GA, Abd ElKader HAM, El-Marasy SA, Zaki ER, Bashandy SAE., Arbid MS, Farrag AH. Pharmacological Effects of Ethanol Extract of Artemisia Herba Alba in Streptozotocin-induced Type 1 Diabetes Mellitus in Rats. Biochem Pharmacol, 2015; 4 (6): 1-13.http://dx.doi.org/10.4173/21670501.1000196.

Abdel Jaleel GA, Abdallah HMI, Gomaa NE. Pharmacological effects of ethanol extract of Egyptian Artemisia herba-albain rats and mice. Asian Pac J Trop Biomed, 2016; 6 (1): 44-49.

Aebi H. 1984. Catalase. In: Bergmeyer, ed. Methods in Enzymatic Analysis. New York 674-684.

Apfel SC, Asbury A K, Bril V, Burns TM, Campbell JN, Chalk CH, Dyck PJ, Dyck PJ, Feldman EL, Fields HL, Grant IA, Griffin JW, Klein CJ, Lindblom U, Litchy WJ, Low PA, Melanson M, Mendell JR, Merren MD, O'Brien PC, Rendell M, Rizza RA, Service FJ, Thomas PK, Walk D, Wang AK, Wessel K, Windebank AJ, Ziegler D, Zochodne DW. Positive neuropathic sensory symptoms as endpoints in diabetic neuropathy trials. J NeurolSci, 2001; 189 (1-2): 3-5.

Aziza SAH, El-Haggar M, Abo-ZaidOA, Hassanien MR, ElShawarby R. Biomarkers of Oxidative Stress of Sciatic Nerve Tissues in Experimental Diabetic Neuropathy. Journal of Medical Sciences, 2014; 14 (1): 12-20. DOI: 10.3923/jms.2014.12.20.

Balbinot LF, Canani LH, Robinson CC, Achaval M, Zaro MA. Plantar thermography is useful in the early diagnosis of diabetic neuropathy. Clinics (Sao Paulo), 2012; 67 (12): 1419-25.

Barrière DA, Rieusset J, Chanteranne D, Busserolles J, Chauvin MA, Chapuis L, Salles J, Dubray C, Morio B. Paclitaxel therapy potentiates cold hyperalgesia in streptozotocin-induced diabetic rats through enhanced mitochondrial reactive oxygen species production and TRPA1 sensitization. Pain, 2012; 153 (3): 553-561. doi: 10.1016/j.pain.2011.11.019. Epub 2011 Dec 15.

Blois MS. Antioxidant determinations by the use of a stable free radical. Nature, 1958; 26: 1199-1200.

Boulton AJ. The diabetic foot: from art to science. The 18th Camillo Golgi Lecture. Diabetologia, 2004; 47 (8): 1343-1353.

Bradford MM.A rapid and sensitive method for the quantitation of microgram quantities of protein utilizing the principle of protein-dye binding. Anal Biochem, 1976; 72: 248-54.

Brownlee M. The pathobiology of diabetic complications a unifying mechanism. Diabetes, 2005; 54 (6): 1615-1625.
Calcutt NA. Modeling diabetic sensory neuropathy in rats. Methods Mol Med, 2004; 99: 55-65. DOI:10.1385/1-59259-770-X:055.

Callaghan BC, Little AA, Feldman EL, Hughes RA .Enhanced glucose control for preventing and treating diabetic neuropathy. Cochrane Database Syst Rev, 2012; (6): CD007543.

Chung SS, Ho EC, Lam KS, Chung SK. Contribution of polyol pathway to diabetes-induced oxidative stress. J Am Soc Nephrol, 2003; 14 (8 Suppl 3): S233-6.

Courteix C, Bardin M, Chantelauze C, Lavarenne J, Eschalier A. Study of the sensitivity of the diabetes-induced pain model in rats to a range of analgesics. Pain, 1994; 57: 153-160.

Courteix C, Bardin M, Massol J, Fialip J, Lavarenne J, Eschalier A. Daily insulin treatment relieves long-term hyperalgesia in streptozocin diabetic rats. Neuroreport, 1996; 7 (12): 1922-1924.

Dae-Ok K, Chun O, Kim YJ, Moon H and Lee CY, Quantification of polyphenolics and their antioxidant capacity in fresh Plums. J Agric Food Chem, 2003; 51: 6509-6515. 1959; 82: 70-77.

Ellman GL. Tissue sulfhydryl groups. Arch BiochemBiophys,

Edwards JL, Vincent AM, Cheng HT, Feldman EL. Diabetic Neuropathy: Mechanisms to Management PharmacolTher,2008; 120: 134.

Feillet-Coudray C, Rock E, Coudray C, Grzelkowska K, AzaisBraesco V, Dardevet D, Mazur A. Lipid peroxidation and antioxidant status in experimental diabetes. Clin Chem Acta, 1999; 284 (1): 31-43.

Figueroa -Romero C, Sadidi M, Feldman EL. Mechanisms of disease: the oxidative stress theory of diabetic neuropathy. Rev. Endocr Metab Disord, 2008; 9: 301-314.

Fowler MJ. Microvascular and macrovascular complications of diabetes. ClinDiabet, 2008; 26: 77-82.

Gilron I, Watson CP, Cahill CM, Moulin DE. Neuropathic pain: A practical guide for the clinician, CMAJ, 2006; 175: 265-275.

Habig WH, Pabst MJ, Jakoby WB. Glutathione S-transferases: The first enzymatic step in mercapturic acid formation. JBiolChem, 1974; 249:7130-7139.

Hounsom L, Tomlinson DR. Does neuropathy develop in animal models? Clin Neurosci, 1997; 4 (6): 380-389.

Kamboj SS, Vasishta RK, Sandhir R. N acetylcysteine inhibits hyperglycemia-induced oxidative stress and apoptosis markers in diabetic neuropathy. J Neurochem, 2010; 112: 77-91.

Kamei J, Zushida K, Morita K, Sasaki M, Tanaka S. Role of vanilloid VR1 receptor in thermal allodynia and hyperalgesia in diabetic mice. Eur J Pharmacol, 2001; 422 (1-3): 83-86.

Kamei J, Mizoguchi H, Narita M, Tseng L F. Therapeutic potential of PKC inhibitors in painful diabetic neuropathy. Expert Opin.Investig. Drugs, 2001a; 10:1653-1664.

Mak DH, Ip SP, Li PC, Poon MK, KO KM. Alterations in tissue glutathione antioxidant system in streptozotocin induced diabetic rats. Mol Cell Biochem, 1996; 162 (2): 153-158.

Melton LJ III, Dyck PJ. 1999. Diabetic polyneu-ropathy. In: Dyck PJ, Thomas PK, editors. Diabetic Neuropathy. 2nd ed. Philadelphia: W.B. Saunders 255-278.

Mizisin A. Schwann cells in diabetic neuropathy. J Mol Cell Biol, 2004; 31:1105-1116.

Mohan Y, Jesuthankaraj GN, Ramasamy Thangavelu N. Antidiabetic and Antioxidant Properties of Triticumaestivum in Streptozotocin-Induced Diabetic Rats. Adv Pharmacol Sci, 2013; 716073.doi: 10.1155/2013/716073. Epub 2013 Dec 14.

Moufid A, Eddouks M.. Artemisia herbaalba: a popular plant with potential medicinal properties. Pak J BiolSci, 2012; 15 (24): 1152 1159.

Nourooz-Zadeh J, Rahimi A, Tajaddini-Sarmadi J, Tritschler H, Rosen P, Halliwell B, Betteridge DJ. Relationships between plasma measures of oxidative stress and metabolic control in NIDDM. Diabetologia, 1997; 40 (6): 647-653. DOI: 10.1007/s001250050729.

Ohkawa H, Ohishi N, Yagi K. Assay for lipid peroxides in animal tissues by thiobarbituric acid reaction. Anal Biochem 1979; 95: 351-358. 
Ohsawa M, Kamei J . Possible involvement of spinal protein kinase $\mathrm{C}$ in thermal allodynia and hyperalgesia in diabetic mice.Eur $\mathrm{J}$ Pharmacol, 1999; 372 (3): 221-228.

Pieber K, Herceg M, Paternostro-Sluga T. Electrotherapy for the treatment of painful diabetic peripheral neuropathy: a review. J Rehabil Med, 2010; 42 (4): 289-95. doi: 10.2340/16501977-0554.

Singleton VL and Rossi JA, Colorimetry of total phenolics with phosphomolybdicphosphotungstic acid reagents. Amer J EnolViticult, 1965; 16: 144-158.

Sugimoto K, Rashid IB, Shoji M, Suda T, Yasujima M. Early changes in insulin receptor signaling and pain sensation in streptozotocininduced diabetic neuropathy in rats. J Pain, 2008; 9 (3): $237-$ 245. doi: 10.1016/j.jpain.2007.10.016. Epub 2007 Dec 3.

Tesfaye S, Tandan R, Bastyr EJ 3rd, Kles KA, Skljarevski V, Price K L. Factors that impact symptomatic diabetic peripheral neuropathy in placeboadministered patients from two 1-year clinical trials. Diabetes Care, 2007; 30 (10): 2626-2632.

Tesfaye S, Boulton AJ, Dyck PJ, Freeman R, Horowitz M, Kempler P, Lauria G, Malik RA, Spallone V, Vinik A, Bernardi L, Valensi P. Toronto Diabetic Neuropathy Expert Group. Diabetic neuropathies: update on definitions, diagnostic criteria, estimationof severity, and treatments. Diabetes Care, 2010; 33 (10): 2285-93.

Thome J, Pesold B, Baader M, Hu M, Gewirtz JC, Duman RS, Henn FA. Stress differentially regulates synaptophysin and synaptotagmin expression in hippocampus. Biol Psychiatry, 2001; 50 (10): 809-812.

Vincent AM, Callaghan BC, Smith AL, Feldman EL . Diabetic neuropathy: cellular mechanisms as therapeutic targets. Nat Rev Neurol, 2011; 7 (10):573-83. doi: 10.1038/nrneurol.2011.137.
Wohaieb SA, Godin, DV. Alterations in free radical tissuedefense mechanisms in streptozocin induced diabetes in rat: Effects of insulin treatment. Diabetes, 1987; 36 (9): 1014-1018.

Woolfe CJ, Mc Donald AD. The evaluation of the analgesic action of pethidine hydrochloride (demerol). J Pharmacol Exp Ther, 1962; 80: 300-307

Zherebitskaya E, Akude E, Smith DR, Fernyhough P. Development of selective axonopathy in adult sensory neurons isolated from diabetic rats: role of glucose-induced oxidative stress. Diabetes, 2009; 58: 1356-1364. doi: 10.2337/db09-0034. Epub 2009 Feb 27.

Ziegler D, Ametov A, Barinov A, Dyck PJ, Gurieva I, Low PA, Munzel U, Yakhno N, Raz I, Novosadova M, Maus J, Samigullin R. Oral treatment with alpha-lipoic acid improves symptomatic diabetic polyneuropathy: the SYDNEY 2 trial. Diabetes Care, 2006; 29: 23652370

\section{How to cite this article:}

El-Marasy SA, Zaki ER, Abdallah HMI, Arbid MS. Therapeutic effects of aqueous, methanol and ethanol extracts of Egyptian Artemisia herba-alba in STZ-induced diabetic neuropathy in rats. J App Pharm Sci, 2017; 7 (03): 180-187. 